\title{
Pengaruh Ukuran Perusahaan, Kepemilikan Institusional, dan Konservatisme Akuntansi pada Tax Avoidance
}

\author{
I Gusti Agung Istri Windaryani ${ }^{1}$ \\ Fakultasi Ekonomi dan Bisnis \\ Universitas Udayana, Indonesia \\ Email: agungwinda93@gmail.com
}

\author{
I Ketut Jati ${ }^{2}$ \\ Fakultas Ekonomi dan Bisnis \\ Universitas Udayana, Indonesia
}

\begin{abstract}
ABSTRAK
Penelitian ini bertujuan untuk memperoleh bukti empiris mengenai pengaruh ukuran perusahaan, kepemilikan institusional, dan konservatisme akuntansi pada tax avoidance di Perusahaan Sektor Pertambangan yang terdapat di BEI periode 2015-2018. Sampel ditentukan menggunakan metode nonprobability sampling dengan teknik purposive sampling, diperoleh sebanyak 11 perusahaan dengan tahun pengamatan selama 4 tahun sehingga diperoleh data sebanyak 44 amatan. Teknik analisis data menggunakan uji Regresi Linier Berganda dengan program SPSS. Hasil penelitian ini menunjukan bahwa ukuran perusahaan dan konservatisme akuntansi memiliki pengaruh negatif pada tax iavoidance sedangkan kepemilikan institusional tidak memiliki pengaruh pada tax avoidance. Hal tersebut berarti semakin besar ukuran suatu perusahaan dan semakin perusahaan menerapkan konservatisme.
\end{abstract}

Kata Kunci: Ukuran Perusahaan; Kepemilikan Institusional; Konservatisme Akuntansi; Tax Avoidance.

The Effect of Company Size, Institutional Ownership, and Accounting Conservatism on Tax Avoidance

\section{ABSTRACT}

This study aims to obtain empirical evidence regarding the effect of company size, institutional ownership, and accounting conservatism on tax avoidance in the Mining Sector Companies contained on the Stock Exchange in the 2015-2018. The sample was determined using the nonprobability sampling method with a purposive sampling technique, obtained by 11 companies with a year of observation for 4 years so as to obtain 44 observations. Data analysis techniques using the Multiple Linear Regression test with the SPSS program. The research result that the size of company and accounting conservatism give a negative effect on tax avoidance while institutional ownership has no effect on tax avoidance. This shows that the larger the size of a company and the more companies apply accounting conservatism, the lower the practice of tax avoidance.

Keywords: Company Size; Ownership Institutional; Accounting Conservatism; Tax Avoidance.

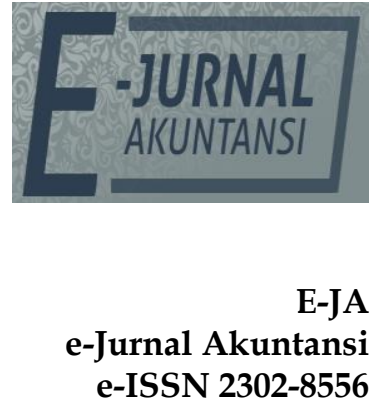

Vol. 30 No. 2

Denpasar, Februari 2020

Hal. 375-387

Artikel Masuk: 18 November 2019

Tanggal Diterima: 15 Januari 2020 


\section{PENDAHULUAN}

Penerimaan negara dari sektor pajak memiliki peran penting dalam pembiayaan belanja negara yang berfungsi untuk meningkatkan kesejahteraan dan kemakmuran rakyat. Menurut Tandean (2016), ada beberapa hambatan yang menyebabkan pemungutan pajak di Indonesia tidak efektif, salah satunya wajib pajak yang berupaya melakukan manajemen pajak terutangnya baik melalui tindakan penghindaran pajak (tax avoidance)maupun penggelapan pajak (tax evasion). Strategi perencanaan pajak yang menggunakan struktur kelompok yang kompleks untuk meminimalkan beban pajak perusahaan dapat dilakukan tanpa melanggar hukum(Thomsen \& Watrin, 2018). Tax avoidance merupakan upaya perusahaan dalam manajemen pajak penghasilan yang tidak melanggar peraturan perundang-undangan sehingga legal dan aman. Praktik tax avoidance umumnya dilakukan dengan memanfaatkan kelemahan yang terdapat dalam undang-undang dan peraturan perpajakan itu sendiri (Putra, et al., 2018). Sementara itu, penggelapan pajak atau yang dikenal dengan tax evasion merupakan upaya menghindari pajak terutang secara illegal dan tindakan tersebut melanggar hukum (Sari, 2015: 54).Pelaksanaan tax avoidance dalam perusahaan dilakukan oleh manajer dengan tujuan memperbesar keuntungan perusahaan agar sesuai dengan harapan pemegang saham (Desai \& Dharmapala, 2009). Praktik tersebut dapat menyebabkan penurunan nilai dan reputasi perusahaan karena mengurangi jumlah beban pajaknya (Lestari \& Wardhani, 2015). Risiko praktik penghindaran pajak yang dilakukan oleh perusahaa adalah akan mempengaruhi keberadaan dan reputasi sebuah perusahaan. (Annuar, et al., 2014).

Self assessment systemmerupakan sistem pemungutan pajak penghasilan yang berlaku di Indonesia dimana wajib pajakberperan aktif dalam menghitung dan membayar sendiri jumlah pajak terutang, pajak yang dapat dikreditkan, dan pajak yang telah dibayar serta mengisi dan melaporkan SPT (Surat Pemberitahuan) dan SSP (Surat Setoran Pajak) ke kantor pajak. Penerapan self assessment system dalam kenyataannyarentan terhadap adanya penyelewengan dan pelanggaran yang salah satunya adalah penghindaran pajak (Mulyani, et al., 2014). Pada tanggal 30 Desember 2016, pemerintah Republik Indonesia menerbitkan Peraturan Menteri Keuangan No. 213 PMK. 03/2016 yang mengatur jenis dokumen dan/atau informasi tambahan yang harus disimpan oleh wajib pajak yang melakukan transaksi dengan pihak terkait atau melalui prosedur manajemen. Peraturan ini bertujuan untuk mengurangi penghindaran pajak perusahaan multinasional (Sari, et al., 2017).

Salah satu fenomena tax avoidance ditunjukkan melalui penerbitan SKPKB (Surat Ketetapan Pajak Kurang Bayar) berdasarkan hasil pemeriksaan oleh DJP (Direktorat Jenderal Pajak) kepada perusahaan karena suatu perusahaan memiliki tambahan jumlah pajak kurang bayar (Resmi, 2012: 34). Adapun perusahaan pertambangan yang menerima SKPKB dapat dilihat pada Tabel 1. berikut. 
Tabel 1. Perusahaan sektor pertambangan yang terdaftar di Bursa Efek Indonesia yang menerima SKPKB periode 2015-2018

\begin{tabular}{ccc}
\hline Tahun & Jumlah Perusahaan & Jumlah Kurang Bayar (Rp) \\
\hline 2015 & 4 & 4.829 .087 .475 \\
2016 & 6 & 7.251 .872 .992 \\
2017 & 3 & 16.441 .854 .084 \\
2018 & 5 & 27.304 .885 .385 \\
\hline
\end{tabular}

Sumber: Data Penelitian, 2019

Berdasarkan Tabel 1. dapat dilihat bahwa jumlah perusahaan yang menerima SKPKB mengalami penurunan dan peningkatan dari tahun ke tahun, namun jumlah kurang bayar dari perusahaan tersebut mengalami peningkatan dari tahun 2015 sampai 2018. Perusahaan yang menerima SKPKB tersebut dianggap tidak benar sehingga kurang jujur dalam melaporkan jumlah pajaknya, dan hal tersebut tidak sesuai dengan harapan pemerintah dalam pemungutan pajak khususnya dalam praktik self assessement system (Dwiyanti dan Jati, 2019).Penelitian dari Ayuningtyas \& Sujana (2018) menyebutkan bahwa kasus penghindaran pajak merupakan masalah serius di Indonesia dan sebagian besar dilakukan oleh wajib pajak badan yaitu sebesar 80 persen dan sisanya adalah wajib pajak orang pribadi. Wajib pajak badan yang banyak melakukan praktik penghindaran pajak sebagian besar yang bergerak di sektor mineral dan batubara, perusahaan asing, serta perusahaan berbadan hukum Indonesia tetapi kepemilikannya oleh asing.

Banyak faktor yang mempengaruhi praktik tax avoidance. Penelitian oleh Mahulae, et al., (2016) menyebutkan kepemilikian institusional, kepemilikan manajerial, dan komite audit sebagai faktor yang mempengaruhi tax avoidance. Dewinta \& Setiawan (2016) menyebutkan bahwa praktik tax avoidance dipengaruhi oleh ukuran perusahaan, umur perusahaan, profitabilitas, leverage, dan pertumbuhan penjualan. Faktor lain yang mempengaruhi praktik tax avoidance adalah konservatisme akuntansi, kepemilikan manajerial, dan dewan komisaris yang sesuai dengan penelitian dari Pramudito \& Sari (2015).

Penelitian ini menggunakan variabel ukuran perusahaan, kepemilikan institusional, dan konservatisme akuntansi sebagai faktor-faktor yang mempengaruhi diterapkannya praktik tax avoidance. Peneliti mengkombinasikan dan memilih variabel-variabel tersebut karena variabel ukuran perusahaan merupakan suatu skala yang menunjukkan perbandingan besar atau kecilnya suatu perusahaan dan dapat mempengaruhi kinerja perusahaan. Alasan memilih variabel kepemilikan institusional adalah karena kepemilikan institusional yang ada di suatu perusahaan turut serta mempengaruhi kebijakan dalam perusahaan karena memiliki hak suara dalam perusahaan apabila kepemilikannya besar, dan data mengenai kepemilikan institusional selalu ditampilkan dalam laporan keuangan sehingga mudah diakses dibandingkan dengan kepemilikan manajerial. Variabel konservatisme akuntansi dipilih karena belum banyak peneliti yang meneliti pengaruh konservatisme akuntansi pada tax avoidance.

Theory of planned behavior atau teori perilaku terencana menjelaskan bahwa perilaku seseorang dipengaruhi oleh niat seseorang untuk melakukan atau tidak terlibat dalam suatu perilaku. Niat atau rencana tersebut akan mempengaruhi 
individu untuk melakukan hal-hal yang dapat menguntungkan dirinya. (Ayuningtyas \& Sujana, 2018).Niat seseorang untuk berperilaku dipengaruhi oleh sikap terhadap perilaku, norma subjektif dan kontrol perilaku perseptif, yang berinteraksi untuk membentuk perilaku tertentu. Sikap adalah pandangan seseorang terhadap suatu objek yang dinyatakan sebagai perasaan yang menguntungkan atau yang tidak menguntungkan pada suatu objek. Sikap akan mengevaluasi keuntungan atau kerugian yang akan diterima individu dalam mewujudkan perilaku (Sulistianingtyas, et al., 2018)

Irianto, et al., (2017) dalam penelitiannya menyebutkan pengertian ukuran perusahaan adalah skala pengelompokan perusahaan menjadi perusahaan besar dan kecil menurut berbagai cara. Berdasarkan beberapa definisi, dapat dilihat bahwa ukuran perusahaan adalah skala yang menentukan suatu perusahaan yang dapat dilihat dari nilai ekuitas, nilai penjualan, jumlah karyawan, total aset, dan lainnya (Putri, et al., 2019). Ukuran perusahaan berkaitan dengan behavioral beliefs karena perusahaan yang memiliki ukuran yang besar memiliki sumber daya manusia yang berkompeten dalam mengelola perusahaannya dan diharapkan dapat menghasilkan laba yang besar melalui aset yang dimiliki, transaksi yang kompleks dalam perusahaan tersebut.Kepemilikan institusional berkaitan dengan control beliefs. Menurut penelitian dari Khurana \& Moser (2011), apabila suatu perusahaan dimiliki oleh investor institusional maka banyak pihak akan mengawasi jalannya perusahaan tersebut sehingga bisa keputusan-keputusan untuk perusahaan juga akan dipertimbangkan dengan investor institusional termasuk keputusan untuk melakukan tindakan penghindaran pajak atau tidak. Namun, jika kepemilikan institusional tidak memiliki kemampuan untuk mengendalikan manajemen, maka tidak bisa mengurangi perilaku oportunistik manajer (Sadjiarto, et al., 2019).

Norma subjektif berkaitan dengan konservatisme akuntansi yang diterapkan dalam suatu perusahaan. Alasan untuk menggunakan konservatisme akuntansi dalam praktik akuntansi adalah untuk menghadapi adanya kesulitan dan ketidakpastian dalam memprediksi manfaat aset dan liabilitas tertentu di masa depan (Sraheen, et al., 2014). Pengakuan aset dan pendapatan baru dilakukan saat aset atau pendapatan tersebut benar-benar telah diterima perusahaan, sedangkan rugi atau biaya yang terjadi harus segera diakui (Alkurdi, et al., 2017). Konservatisme mengarah pada laporan keuangan yang bias karena kurang relevan dan menurunkan kualitas laba yang didapat, sehingga tidak bisa digunakan untuk itu mengevaluasi risiko perusahaan (Yuniarsih, 2018). Konservatisme akuntansi yang diterapkan dalam suatu perusahaan akan menyebabkan laba yang cenderung rendah sehingga beban pajaknya akan rendah. Suatu perusahaan yang memiliki beban pajak yang rendah, akan cenderung patuh terhadap kewajiban perpajakannya atau dengan kata lain perusahaan itu meminimalkan perilaku penghindaran pajak (tax avoidance).

Luayyi (2012) menyatakan bahwa teori keagenan pada dasarnya menjelaskan bentuk kesepakatan antara pemegang saham dan manajer untuk mengelola perusahaan. Para manajer tidak selalu bertindak sesuai dengan 
harapan terbaik dari pemegang saham sehingga menyebabkan asimetri informasi.

Menurut Dyreng, et al. (2010) pengukuran tax avoidance yang baik digunakan adalah CETR (Cash Effective Tax Rate)karena nilai CETR tidak terpengaruh oleh perubahan estimasi seperti adanya perlindungan pajak. Persentase CETR yang semakin tinggi mengindikasikan bahwa semakin rendah tingkat tax avoidance perusahaan, begitu sebaliknya tingkat persentase CETR yang rendah mengindikasikan bahwa semakin tinggi praktik tax avoidance perusahaan.

Ukuran perusahaan berkaitan dengan behavioral beliefs. Perusahaan yang termasuk dalam skala perusahaan besar diharapkan memiliki sumber daya yang berlimpah yang dapat digunakan untuk tujuan-tujuan tertentu. Salah satunya sumber daya manusia yang bisa mengelola keuangan perusahaan, termasuk mengelola beban pajak perusahaan. Penelitian yang dilakukan oleh Swingly \& Sukartha (2015) serta Siregar \& Widyawati (2016) menyatakan bahwa ukuran perusahaan berpengaruh positif pada tax avoidance.

Perusahaan yang besar memiliki sumber daya manusia yang besar pula dalam mengelola menunjang kemajuan perusahaannya. Salah satunya dalam hal melakukan manajemen terhadap beban pajak, yaitu mengelola pajak perusahaan agar efektif yang dapat dilakukan dengan tindakan penghindaran pajak (tax avoidance). Berdasarkan uraian di atas, hipotesis yang dapat dirumuskan dalam penelitian ini adalah.

$\mathrm{H}_{1}$ : Ukuran perusahaan berpengaruh positif pada tax avoidance.

Kepemilikan institusional berkaitan dengan control beliefs dalam theory of planned behavior yang menyebutkan bahwa keyakinan tentang keberadaan hal-hal yang mendukung atau menghambat perilakunya dan persepsinya tentang seberapa kuat hal-hal tersebut mempengaruhi perilakunya (Hidayat \& Nugroho, 2010). Penelitian yang dilakukan oleh Merslythalia \& Lasmana (2017) menjelaskan adanya pengaruh negatif dari kepemilikan insstitusional pada tax avoidance. Penelitian dari Arianandini \& Ramantha (2018) juga mendukung penelitian tersebut, yang menunjukkan bahwa kepemilikan institusional berpengaruh negatif pada tax avoidance. Pemilik institusional dapat memaksa manajer untuk berfokus pada kinerja ekonomi dalam rangka memajukan perusahaan dan mentaati aturan perpajakan agar repitasi perusahaan tetap baik. Berdasarkan uraian di atas, peneliti merumuskan hipotesis sebagai berikut.

$\mathrm{H}_{2}$ : Kepemilikan institusionalberpengaruh negatif pada tax avoidance.

Normative beliefs berkaitan dengan konservatisme akuntansi, dimana manajer dalam menerapkan konservatisme dalam suatu perusahaan dapat mengelola laba dengan cara penerapan laba yang ketat sehingga laba yang dihasilkan rendah dan beban pajaknya akan rendah. Suatu perusahaan yang memiliki beban pajak yang rendah, akan cenderung patuh terhadap kewajiban perpajakannya atau dengan kata lain perusahaan itu meminimalkan perilaku penghindaran pajak (tax avoidance). Penelitian dari Hartoto (2018) menyebutkan bahwa konservatisme akuntansi memiliki pengaruh positif pada tax avoidance. Sejalan dengan penelitian Sarra, et a.l, (2017), Kurniaty (2016) juga menyebutkan adanya pengaruh signifikan yang negatif dari konservatisme akuntansi terhadap tax avoidance. Laba perusahaan menjadi bias ke bawah apabila suatu perusahaan 
menerapkan konservatisme akuntansi sehingga pajak perusahaan juga akan bias ke bawah. Perusahaan akan meminimalisir tindakan tax avoidance karena bepajak yang dibebankan lebih rendah. Berdasarkan uraian tersebut, maka hipotesis yang dirumuskan sebagai berikut.

$\mathrm{H}_{3}$ : Konservatisme akuntansi berpengaruh negatif pada tax avoidance.

\section{METODE PENELITIAN}

Penelitian tentang tax avoidance ini menggunakan pendekatan kuantitatif yang berbentuk asosiatif. BEI (Bursa Efek Indonesia) merupakan tepat dilakukannya penelitian ini. Ruang lingkup penelitian ini adalah perusahaan-perusahaan sektor pertambangan yang terdaftar di BEI tahun 2015-2018 dengan mengakses situs resmi Bursa Efek Indonesia yaitu www.idx.co.id dan nama-nama perusahaan diperoleh dari situs www.sahamok.com Objek penelitian dalam penelitian ini adalah ukuran perusahaan $\left(X_{1}\right)$, kepemilikan institusional $\left(X_{2}\right)$, konservatisme akuntansi $\left(\mathrm{X}_{3}\right)$, dan tax avoidance $(\mathrm{Y})$. Variabel dependen dalam penelitian ini adalah tax avoidance Variabel independen dalam penelitian ini adalah ukuran perusahaan, kepemilikan institusional, dan konservatisme akuntansi.

Jenis data yang digunakan dalm penelitian ini adalah data kuantitatif yaitu laporan keuangan perusahaan pertambangan yang terdaftar di Bursa Efek Indonesia periode 2015-2018. Data dalam penelitian ini merupakan data sekunder, diperoleh dari laporan keuangan perusahaan pertambangan untuk periode 2015-2018 yang terdaftar di Bursa Efek Indonesia yang diakses melalui laman www.idx.co.id

Pengukuran tax avoidance menurut (Dyreng, et al., 2010) adalah CETR. CETR juga digunakan dalam penelitian (Chen, et al., 2019). Penelitian tax avoidance dengan proksi CETR ini, dihitung menggunakan rumus sebagai berikut.

CETR $=\frac{\text { Cash Tax Paidi, }}{\text { Pretax Income } i, t}$

Keterangan :

Cash Tax Paid $i, t \quad$ : Pembayaran pajak oleh perusahaan I pada laporan arus kas perusahaan periode $t$.

Pretax Income $i, t \quad$ : Laba sebelum pajak perusahaan I pada periode $t$.

Pengukuran variabel ukuran perusahaan dalam penelitian ini menggunakan log total aset, karena dinilai bahwa proksi ini lebih stabil dibandingkan proksi-proksi yang lainnya dan cenderung berkesinambungan antar periode (Jogiyanto, 2016: 259). Ukuran perusahaan dihitung dengan cara sebagai berikut.

Ukuran perusahaan $=$ Log total aset

Indikator yang digunakan untuk mengukur kepemilikan institusional adalah persentase saham yang dimiliki oleh institusi dari seluruh jumlah saham yang beredar (Sunarsih \& Oktaviani, 2016).

Kepemilikan Institusional $=\frac{\text { Total Kepemilikan Saham oleh pihak Institusi }}{\text { Jumlah Saham Beredar }}$

Suatu perusahaan yang menerapkan konservatisme akuntansi dapat diketahui melalui pengukuran konservatisme akuntasu dengan cara mengurangi 
laba bersih dengan arus kas operasi (Hartoto, 2018). Rumus yang digunakan menghitung konservatisme akuntansi adalah sebagai berikut.

Konservatisme Akuntansi $=\frac{(\mathrm{L}-\text { AKO-Depresiasi })}{\text { Total Aset }} \mathrm{x}^{(-1)}$

Keterangan :

$\mathrm{L} \quad=$ Laba Bersih

$\mathrm{AKO}=$ Aliran Kas Operasi

HASIL DAN PEMBAHASAN

Statistik deskriptif dalam penelitian ini memberikan gambaran mengenai data yang tersaji seperti nilai minimum, nilai maksimum, nilai rata-rata (mean) dan standar deviasi.

Tabel 2. Hasil Uji Stastistik Deskriptif

\begin{tabular}{|c|c|c|c|c|c|}
\hline & $\mathrm{N}$ & Minimum & Maksimum & Mean & $\begin{array}{l}\text { Std. } \\
\text { Deviation }\end{array}$ \\
\hline CETR & 44 & 0,076 & 0,740 & 0,380 & 0,151 \\
\hline Ukuran Perusahaan & 44 & 12,178 & 14,010 & 12,819 & 0,439 \\
\hline Kepemilikan & 44 & 0,260 & 0,970 & 0,732 & 0,170 \\
\hline $\begin{array}{l}\text { Konservatisme } \\
\text { Akuntansi }\end{array}$ & 44 & 0,016 & 0,594 & 0,286 & 0,140 \\
\hline
\end{tabular}

Sumber: Data Penelitian, 2019

Tabel 2. menunjukkan bahwa variabel tax avoidance sebagai variabel dependen yang diproksikan dengan CETRmemiliki nilai maksimum sebesar 0,740 dan nilai minimum sebesar 0,076. Rata-rata CETR sebesar 0,380 dan nilai standar deviasi CETR sebesar 0,15. Hasil penyebaran data CETR berdistribusi normal dan tidak bias. Nilai minimum dari variabel ukuran perusahaan sebesar 12,718 dan nilai maksimim sebesar 14,010 . Ukuran perusahaan memiliki rata-rata sebesar 12,819 yang lebih ke arah median atau nilai tengah. Hal ini dapat berarti bahwa perusahaan yang ada di sektor pertambangan seimbang antara perusahaan berukuran besar dan perusahaan berukuran kecil. Ukuran perusahaan memiliki nilai standar deviasi sebesar 0,439 yang menunjukkan adanya penyimpangan dataterhadap nilai rata-ratanya sebesar 0,439. Kepemilikan institusional sebagai variabebebas kedua dalam penelitian ini mempunyai nilai rata-rata sebesar 0,732 , nilai minimum sebesar 0,260 dan nilai maksimum sebesar 0,970. Standar deviasi kepemilikan institusional sebesar 0,170 maka penyimpangan data terhadap nilai rata-ratanya sebesar 0,170. Variabel bebas konservatisme akuntansi yang diproksikan dengan rumus dari Givolyn dan Hayn (2000) memiliki nilai minimum sebesar 0,016 dan nilai maksimim sebesar 0,594. Variabel konservatisme akuntansi memiliki rata-rata sebesar 0,286. Penyimpangan data konservatisme akuntansi terhadap nilai rata-ratanya sebesar 0,140 .

Pada penelitian ini, uji asumsi klasik yang dilakukan meliputi uji normalitas, uji multikolinieritas, uji heteroskedastisitas, dan uji autokorelasi yang dapat dilihat pada Tabel 3 berikut. 
Tabel 3. Hasil Uji Asumsi Klasik

\begin{tabular}{llllll}
\hline Variabel & $\begin{array}{l}\text { Uji } \\
\text { Normalitas }\end{array}$ & Uji Multikoline-aritas & $\begin{array}{l}\text { UjiHeteros- } \\
\text { kedastisitas }\end{array}$ & $\begin{array}{l}\text { Uji Auto- } \\
\text { korelasi }\end{array}$ \\
\cline { 2 - 6 } & $\begin{array}{l}\text { Sig. (2-tailed) } \\
\text { Kolmogorof } \\
\text { Smirnov Z }\end{array}$ & Tolerance & VIF & Sig. & $\begin{array}{l}\text { Durbin } \\
\text { Watson }\end{array}$ \\
\hline $\begin{array}{l}\text { Ukuran } \\
\begin{array}{l}\text { Perusahaan } \\
\text { Kepemilikan }\end{array}\end{array}$ & 0,189 & 0,536 & 1,867 & 0,077 & 1,724 \\
$\begin{array}{l}\text { Institusional } \\
\text { Konservatisme } \\
\text { Akuntansi }\end{array}$ & 0,759 & 1,318 & 0,155 & \\
\hline
\end{tabular}

Sumber: Data Penelitian, 2019

Uji normalitas ini bertujuan untuk mengetahui apakah residual dari model regresi yang dibuat berdistribusi normal atau tidak. Berdasarkan hasil uji normalitas pada tabel 3 dapat dilihat bahwa nilai Kolmogorov-Smirnov sebesar 1,086 dan signifikansi Asymp.Sig.(2-tailed) bernilai 0,189. Dalam uji normalitas ini, dapat dilihat nilai signifikansi uji Kolmogorov-Smirnov lebih besar dari 0,05 maka model regresi tersebut berdistribusi normal.

Uji multikolinieritas dilakukan untuk menguji apakah terdapat korelasi antar variabel-variabel independen dalam model regresi. Hasil uji multikolinieritas pada Tabel 3. pada penelitian ini menghasilkan nilai tolerance dari variabel bebas yaitu ukuran perusahaan, kepemilikan institusional, dan konservatisme akuntansi lebih dari 0,10 dan VIF dari variabel-variabel tersebut kurang dari 10. Hal itu menunjukkan bahwa model regresi tersebut terbebas dari multikolinieritas.

Uji heteroskedastisitas bertujuan untuk mengetahui apakah dalam model regresi terjadi ketidaksamaan varians dari residual satu pengamatan ke pengamatan lain. Berdasarkan hasil uji heteroskedastisitas pada tabel 3 dapat dilihat bahwa nilai signifikansidari variabel bebas yaitu ukuran perusahaan, kepemilikan institusional, dan konservatisme akuntansi masing- masing lebih besar dari $\alpha=0,05$. Hal itu menunjukkan bahwa model regresi tersebut terbebas dari gejala heteroskedastisitas.

Uji autokorelasi dilakukan untuk mengetahui adanya korelasi data dari tahun $t$ dengan tahun sebelumnya. Berdasarkan hasil uji autokorelasi pada tabel 4.3 dapat dilihat bahwa nilai durbin watsonsebesar 1,724. Oleh karena jumlah sampel (n) sebanyak 44 dan jumlah variabel bebas (k) adalah 3, maka diperoleh nilai $\mathrm{dl}=1,374$ dan $\mathrm{du}=1,664$ sehingga diperoleh nilai 4 -du $=2,336$, sehingga menghasilkan $\mathrm{du}<\mathrm{d}<4$-du yaitu 1,664<1,724<2,336, maka dapat disimpulkan bahwa data tersebut tidak terdapat autokorelasi.

Analisis regresi linier berganda dalam penelitian ini dilakukan untuk mengetahui adanya pengaruh dan arah pengaruh variabel bebas terhadap variabel terikat yang diproses dengan menggunakan program Statistical Package for Social Science (SPSS). Hasil Analisis Regresi Linier Berganda dapat dilihat pada Tabl 4. 
Tabel 4. Hasil Analisis Regresi Linier Berganda

\begin{tabular}{|c|c|c|c|c|c|c|}
\hline \multirow[b]{2}{*}{ Model } & & \multicolumn{2}{|c|}{$\begin{array}{l}\text { Unstandardized } \\
\text { Coefficients }\end{array}$} & \multirow{2}{*}{$\begin{array}{l}\text { Standardized } \\
\text { Coefficients } \\
\text { Beta }\end{array}$} & \multirow[b]{2}{*}{$t$} & \multirow[b]{2}{*}{ Sig } \\
\hline & & $B$ & $\begin{array}{l}\text { Std. } \\
\text { Error }\end{array}$ & & & \\
\hline & (Constan) & $-2,721$ & 0,852 & & $-3,194$ & 0,003 \\
\hline & $\begin{array}{l}\text { Ukuran } \\
\text { Perusahaan }\end{array}$ & 0,236 & 0,060 & 0,683 & 3,913 & 0,000 \\
\hline & $\begin{array}{l}\text { Kepemilikan } \\
\text { Institusional }\end{array}$ & $-0,030$ & 0,131 & $-0,033$ & $-0,228$ & 0,820 \\
\hline & $\begin{array}{l}\text { Konservatisme } \\
\text { Akuntansi }\end{array}$ & 0,400 & 0,176 & 0,371 & 2,278 & 0,028 \\
\hline R Square & & 0,122 & & & & \\
\hline Adjusted $\mathrm{R}$ & & & & & & \\
\hline Square & & 0,057 & & & & \\
\hline F Statistik & & 7,091 & & & & \\
\hline Signifikansi & & 0,001 & & & & \\
\hline
\end{tabular}

Sumber: Data Penelitian, 2019

Berdasarkan Tabel 4. diperoleh suatu persamaan regresi sebagai berikut:

$$
\mathrm{Y}=-2,721+0,236 \mathrm{X}_{1}-0,30 \mathrm{X}_{2}+0,400 \mathrm{X}_{3}+\varepsilon
$$

Interpretasi dari persamaan regresi diatas, adalah nilai konstanta $(\alpha)=$ 2,721 , berarti apabila $X_{1}$ (ukuran perusahaan), $X_{2}$ (kepemilikan institusional), dan $\mathrm{X}_{3}$ (konservatisme akuntansi)bernilai sama dengan nol, maka nilai $\mathrm{Y}$ (CETR) sebesar -2,721. Nilai Koefisien $\beta_{1}=0,236$ berarti apabila $X_{1}$ naik 1 satuan, maka nilai $Y$ akan naik sebesar 0,236 . Nilai koefisien $\beta_{2}=-0,030$ menunjukkan bahwa jika nilai $X_{2}$ naik 1 satuan, maka nilai $Y$ akan turun sebesar 0,030 satuan. Nilai koefisien $\beta_{3}=0,400$ menunjukkan bahwa jika nilai $X_{3}$ naik 1 satuan, maka nilai $Y$ akan naik sebesar 0,400 satuan dengan asumsi variabel lainnya konstan.

Uji koefisien determinasi $\left(R^{2}\right)$ bertujuan untuk mengukur seberapa jauh variansi variabel independen dalam menerangkan variansi variabel dependen. Nilai koefisien determinasi adalah antara nol dan satu. Tabel 4 menunjukkan nilai Adjusted $R$ Square pada model sebesar 0,057 yang berarti Tax Avoidance dapat dijelaskan oleh variabel Ukuran Perusahaan, Kepemilikan Institusional, dan Konservatisme Akuntansi sebesar 5,7 persen, sedangkan sisanya sebesar 94,3 persen dijelaskan oleh variable lain di luar model.

Uji $F$ bertujuan, untuk mengetahui apakah semua variabel independen dalam model regresi mempunyai pengaruh secara serempak atau simultan terhadap variabel dependen. Tabel 4 menunjukkan bahwa model memiliki Sig. sebesar 0,001 lebih kecil dari $\alpha=0,05$, yang berarti penelitian ini layak sebagai alat analisis untuk menguji pengaruh variabel independen terhadap variabel dependen. Variabel ukuran perusahaan, kepemilikan institusional, dan konservatisme akuntansi berpengaruh secara bersama-sama terhadap variabel tax avoidance.Uji $t$ bertujuan menunjukkan seberapa jauh pengaruh variabel independen secara individual dalam menerangkan variasi variabel dependen (Ghozali, 2016: 97).

Hipotesis pertama yang dirumuskan dalam penelitian ini yaitu ukuran perusahaan berpengaruh positif pada tax avoidance. Tabel 4.5 menunjukkan bahwa nilai signifikansi uji t untuk variabel ukuran perusahaan sebesar 0,000 lebih kecil dari $a=0,05$ dengan koefisien regresi bernilai positif sebesar 0,236. 
Berdasarkan hal tersebut, maka hipotesis pertama $\left(\mathrm{H}_{1}\right)$ yang dirumuskan dalam penelitian ini ditolak. Ukuran perusahaan memiliki positif pada CETR dan berpengaruh negatif pada tax avoidance.

Tabel 5. Hasil Uji Hipotesis

\begin{tabular}{llll}
\hline Variabel & $\begin{array}{l}\text { Koefisien } \\
\text { Regresi }\end{array}$ & thitung & Sig \\
\hline Ukuran Perusahaan & 0,236 & 3,913 & 0,000 \\
Kepemilikan Institusional & $-0,030$ & $-0,228$ & 0,820 \\
Konservatisme Akuntansi & 0,400 & 2,278 & 0,028
\end{tabular}

Sumber: Data penelitian, 2019

Hipotesis kedua menyatakan bahwa kepemilikan institusional berpengaruh negatif pada tax avoidance. Pada tabel diatas dapat dilihat bahwa nilai signifikansi uji $\mathrm{t}$ untuk variabel ukuran perusahaan sebesar 0,820 lebih besar dari $a=0,05$ dengan koefisien regresi bernilai negatif sebesar 0,030. Hipotesis kedua $\left(\mathrm{H}_{2}\right)$ dalam penelitian ini ditolak, dimana kepemilikan institusional tidak berpengaruh pada tax avoidance.Hipotesis ketiga menyebutkan bahwa konservatisme akuntansi berpengaruh negatif pada tax avoidance. Nilai signifikansi uji t untuk variabel konservatisme akuntansi sebesar 0,028 lebih kecil dari $\alpha=0,05$ dengan koefisien regresi bernilai positif sebesar 0,400. Berdasarkan hal tersebut, maka hipotesis ketiga $\left(\mathrm{H}_{3}\right)$ dalam penelitian ini diterima. Artinya konservatisme akuntansi berpengaruh positif pada CETR dan berpengaruh negatif pada tax avoidance.

\section{SIMPULAN}

Simpulan yang dapat ditarik berdasarkan hasil dan pembahasan yang sudah dijelaskan sebelumnya maka dapat adalahukuran perusahaan berpengaruh negatif pada tax avoidance. Hal ini berarti bahwa semakin besar ukuran perusahaan maka semakin kecil tindakan tax avoidance yang dilakukan.Variabel kepemilikan institusional tidak memiliki pengaruh terhadap praktik tax avoidance dalam perusahaan. Konservatisme akuntansi berpengaruh negatif pada tax avoidance. Hal ini berarti apabila suatu perusahaan menerapkan konservatisme akuntansi yang semakin tinggi, maka semakin rendah praktik tax avoidance yang dilakukan.

Peneliti menyarankan kepada pihak regulator khususnya kantor pajak untuk membuat regulasi yang lebih baik mengenai pajak agar penerimaan negara di sektor pajak dapat mencapai target.Pemerintah disarankan untuk mengawasi dan membuat kebijakan yang lebih tegas agar dapat mengurangi tindakan tax avoidance.Peneliti menyarankan kepada perusahaan agar tidak melakukan praktik penghindaran pajak atau tax avoidance karena akan berakibat mendapat sanksi berupa denda serta jatuhnya reputasi perusahaan.Bagi penelitian selanjutnya disarankan untuk menambah atau mempertimbangkan kemungkinan variabel lain yang dapat mempengaruhi tax avoidance seperti sales growth, proksi-proksi good corporate governance, atau variabel yang belum banyak diteliti seperti financial disstress. Peneliti selanjutnya juga disarankan 
menggunakan perusahaan-perusahaan sektor lainnya yang terdapat di BEI atau menambah periode tahun penelitian.

\section{REFERENSI}

Alkurdi, A., Al-Nimer, M., \& Dabaghia, M. (2017). Accounting conservatism and ownership structure effect: A look at industrial and financial jordanian listed companies. Journal of Environmental Accounting and Management, 5(2), 153-169. https:// doi.org/10.5890/JEAM.2017.06.007

Annuar, H. A., Salihu, I. A., \& Obid, S. N. S. (2014). Corporate Ownership, Governance and Tax Avoidance: An Interactive Effects. Procedia - Social and Behavioral Sciences, 164(August), 150-160. https://doi.org/10.1016/j.sbspro.2014.11.063

Arianandini, P. W., \& Ramantha, I. W. (2018). Pengaruh Profitabilitas, Leverage, dan Kepemilikan Institusional pada Tax Avoidance. Jurnal Akuntansi Fakultas Ekonomi Dan Bisnis Universitas Udayana, 22(3), 2088-2116. https://doi.org/10.1017/CBO9781107415324.004

Ayuningtyas, N. P. W., \& Sujana, I. K. (2018). Pengaruh Proporsi Komisaris Independen, Leverage, Sales Growth, Dan Profitabilitas Pada Tax Avoidance. E-Jurnal Akuntansi. https:// doi.org/10.24843/eja.2018.v25.i03.p10

Desai, M. A., \& Dharmapala, D. (2009). Corporate tax avoidance and firm value. Review of Economics and Statistics, 91(3), 537-546. https:/ / doi.org/10.1162/rest.91.3.537

Dwiyanti, I. A. I., \& Jati, I. K. (2019). Pengaruh Profitabilitas, Capital Intensity, dan Inventory Intensity pada Penghindaran Pajak. E-Jurnal Akuntansi, 27, 2293. https:// doi.org/10.24843/eja.2019.v27.i03.p24

Dyreng, S. D., Hanlon, M., \& Maydew, E. L. (2008). Long-run corporate tax avoidance. Accounting Review, 83(1), 61-82. https://doi.org/10.2308/accr.2008.83.1.61

Ghozali, imam. (2016). Aplikasi Analisis Multivariete Dengan Program IBM SPSS 23 (Edisi 8). In Universitas Diponegoro. https://doi.org/https://doi.org/10.3929/ethz-b-000238666

Hartoto, R. I. (2018). Pengaruh Financial Distress, Corporate Governance dan Konservatisme Akuntansi terhadap Tax Avoidance (Studi Empiris pada perusahaan perbankan yang listing di BEI tahun 2015-2017). Jurnal Fakultas Ekonomi Universitas Islam Indonesia Yogyakarta, 10(2), 1-15.

Hidayat, W., \& Nugroho, A. . (2010). Studi Empiris Theory of Planned Behavior dan Pengaruh Kewajiban Moral pada Perilaku Ketidakpatuhan Pajak Wajib Pajak Orang Pribadi. Jurnal Akuntansi Dan Keuangan, 12(2), 2338-2348. https:// doi.org/10.1097/00042737-200205000-00005

Irianto, D. B. S., \& S.Ak, A. W. (2017). The Influence of Profitability, Leverage, Firm Size and Capital Intensity Towards Tax Avoidance. International Journal of Accounting and Taxation, 5(2), 33-41. https:// doi.org/10.15640/ijat.v5n2a3

Jogiyanto. (2010). Portofolio dan Investasi Teori dan Aplikasi. E-Jurnal Manajemen.

Khurana, I. K., \& Moser, W. J. (2011). Institutional Ownership and Tax Aggressiveness. SSRN Electronic Journal, (573), 0-42. https://doi.org/10.2139/ssrn.1464106 
Kurniaty. (2016). Pengaruh Konservatisme Akuntansi dan Struktur Kepemilikan terhadap Aggresive Tax Avoidance (Studi Empiris pada Perusahaan Manufaktur yang Terdaftar di Bursa Efek Indonesia Tahun 2011-2015). Jurnal Akuntansi Fakultas Ekonomi Universitas Tanjungpura, 3(1), 209-217. https://doi.org/https://doi.org/10.3929/ethz-b-000238666

Lestari, N., \& Wardhani, R. (2015). The effect of the tax planning to firm value with moderating board diversity. International Journal of Economics and Financial Issues, 5(2010), 315-323.

Luayyi, S. (2012). Teori Keagenan Dan Manajemen Laba Dari Sudut Pandang Etika Manajer. El Muhasaba: Jurnal Akuntansi, 1(2), 199-216. https://doi.org/10.18860/em.v1i2.1871

Mahulae, E. E., Pratomo, D., \& Nurbaiti, A. (2016). Pengaruh Kepemilikan Institusional, Kepemilikan Manajerial, dan Komite Audit terhadap Tax Avoidance. Akuntansi Fakultas Ekonomi Dan Bisnis Universitas Telkom, 3(2), 1626-1633. https://doi.org/10.4234/jjoffamilysociology.28.250

Merslythalia, R., \& Lasmana, M. S. (2017). Pengaruh Kompetensi Eksekutif, Ukuran Perusahaan, Komisaris Independen, dan Kepemilikan Institusional Terhadap Tax Avoidance. Jurnal Ilmiah Akuntansi Dan Bisnis, 117. https://doi.org/10.24843/jiab.2016.v11.i02.p07

Mulyani, S., Darminto, \& Endang, M. G. (2014). Pengaruh Karakteristik Perusahaan, Koneksi Politik dan Reformasi Perpajakan terhadap Penghindaran Pajak. Jurnal Mahasiswa Perpajakan, 2(1), 1-47. https://doi.org/http:// perpajakan.studentjournal.ub.ac.id

Pramudito, B., \& Ratna Sari, M. (2015). Pengaruh Konservatisme Akuntansi, Kepemilikan Manajerial Dan Ukuran Dewan Komisaris Terhadap Tax Avoidance. E-Jurnal Akuntansi, 13(3), 737-752.

Putra, P. D., Syah, D. H., \& Sriwedari, T. (2018). Tax Avoidnce: Evidence of As a proof of Agency Theory and Tax Planning. International Journal of Research \& Review, 5(9), 52-60. https:/ / doi.org/10.1107/s0108768109011057

Putri, R. T., Ulum, I., \& Prasetyo, A. (2019). Company Risk, Size, Fiscal Loss Compensation, and Tax Avoidance: Evidence from Indonesian Islamic Companies. Journal of Innovation in Business and Economics, 2(02), 87. https://doi.org/10.22219/jibe.v2i02.7323

Resmi, S. (2012). Perpajakan Teori dan Kasus (Edisi 6). Jakarta: Salemba Empat.

Rosa Dewinta, I., \& Ery Setiawan, P. (2016). Pengaruh Ukuran Perusahaan, Umur Perusahaan, Profitabilitas, Leverage, Dan Pertumbuhan Penjualan Terhadap Tax Avoidance. E-Jurnal Akuntansi.

Sadjiarto, A., Monica, C. C., \& Budiarti, W. R. (2019). Ownership Structure and Earnings Management in Indonesian Listed Banks. Journal of Economics and Business, 2(1), 261-272. https:/ / doi.org/10.31014/aior.1992.02.02.85

Sari, D. (2015). Konsep Dasar Perpajakan. Bandung: Refika Aditama.

Sari, D. K., Utama, S., \& Rossieta, H. (2017). Tax Avoidance, Related Party Transactions, Corporate Governance and the Corporate Cash Dividend Policy. Journal of Indonesian Economy and Business, 32(3), 190. https://doi.org/10.22146/jieb.28658

Sarra, H. D. (2017). Pengaruh Konservatisme Akuntansi, Komite Audit Dan Dewan Komisaris Independen Terhadap Penghindaran Pajak (Studi Empiris 
Pada Industri Kimia dan Logam di Bursa Efek Indonesia Periode 2010-2014). Competitive Jurnal Akuntansi Dan Keuangan, 1(1), 63. https://doi.org/10.31000/competitive.v1i1.108

Siregar, R., \& Widyawati, D. (2016). Pengaruh Karakteristik Perusahaan Terhadap Penghindaran Pajak pada Perusahaan Manufaktur di Bei. Jurnal Ilmu $\mathcal{E}$ Riset Akuntansi.

Sraheen, O. A. D. A.-D., Fadzil, Bt, F. H., Ismail, \& Syed, S. S. Bin. (2014). The Influence of Corporate Ownership Structure and Board Members' Skills on the Accounting Conservatism: Evidence from Non-Financial Listed Firms in Amman Stock Exchange. International Journal of Accounting and Financial Reporting, 4(1), 177. https:// doi.org/10.5296/ijafr.v4i1.5661

$\mathrm{Su}, \mathrm{K} ., \mathrm{Li}, \mathrm{B} .$, \& Ma, C. (2019). Corporate dispersion and tax avoidance. Chinese Management Studies. https:// doi.org/10.1108/CMS-04-2018-0497

Sulistianingtyas, V., Rosidi, R., \& Subekti, I. (2018). A Perspective of Theory of Planned Behavior and Attribution Theory for PBB P2 Taxpayer Compliance in Probolinggo. Journal of Accounting and Business Education, 2(2), 320-347. https://doi.org/10.26675/jabe.v2i2.11232

Sunarsih, U., \& Oktaviani, K. (2016). Good Corporate Governance in Manufacturing Companies Tax Avoidance. ETIKONOMI. https://doi.org/10.15408/etk.v15i2.3541

Swingly, C., \& Sukartha, I. (2015). Pengaruh Karakter Eksekutif, Komite Audit, Ukuran Perusahaan, Leverage Dan Sales Growth Pada Tax Avoidance. EJurnal Akuntansi, 10(1), 47-62.

Tandean, V. A. (2016). Good Corporate Governance Dan Ukuran Perusahaan Pengaruhnya Pada Tax Avoidance. Jurnal Ilmiah Akuntansi Dan Bisnis, 978979. https:// doi.org/10.24843/jiab.2016.v11.i01.p07.

Thomsen, M., \& Watrin, C. (2018). Tax avoidance over time: A comparison of European and U.S. firms. Journal of International Accounting, Auditing and Taxation, 33 (November), 40-63. https://doi.org/10.1016/j.intaccaudtax.2018.11.002.

Yuniarsih, N. (2018). The effect of accounting conservatism and corporate governance mechanism on tax avoidance. Academic Research International, 9(3), 68-76. 